\title{
Article \\ Physical and Mechanical Properties of Rural-Road Pavement Concrete in South Korea Containing Air-Cooled Blast-Furnace Slag Aggregates
}

\author{
Byung-Hwan Ahn ${ }^{1}$, Su-Jin Lee ${ }^{2}$ and Chan-Gi Park ${ }^{1, *}$ \\ 1 Department of Regional Construction Engineering, Kongju National University, Yesan 32439, Korea; \\ an641006@korea.kr \\ 2 Department of Architectural Engineering, Keimyung University, Daegu 42601, Korea; sjlee@gw.kmu.ac.kr \\ * Correspondence: cgpark@kongju.ac.kr
}

Citation: Ahn, B.-H.; Lee, S.-J.; Park, C.-G. Physical and Mechanical Properties of Rural-Road Pavement Concrete in South Korea Containing Air-Cooled Blast-Furnace Slag Aggregates. Appl. Sci. 2021, 11, 5645. https://doi.org/10.3390/app11125645

Academic Editor: Luigi Biolzi

Received: 21 May 2021

Accepted: 15 June 2021

Published: 18 June 2021

Publisher's Note: MDPI stays neutra with regard to jurisdictional claims in published maps and institutional affiliations.

Copyright: (c) 2021 by the authors. Licensee MDPI, Basel, Switzerland. This article is an open access article distributed under the terms and conditions of the Creative Commons Attribution (CC BY) license (https:/ / creativecommons.org/licenses/by/ $4.0 /)$.

\begin{abstract}
The purpose of this study was to assess the physical and mechanical properties of pavement concrete for rural roads of South Korea made with air-cooled slag aggregate, which is an industrial byproduct. This study assessed the physical and chemical properties according to the following performance requirements based on the design criteria of the Korea Ministry of Agriculture's Agricultural Production Infrastructure Maintenance Business Plan and the Korea Expressway Corporation's Highway Construction Specialized Specifications: slump of $80 \mathrm{~mm}$ or greater, air content of $4.5 \pm 1.5 \%$, compressive strength of at least $21 \mathrm{MPa}$, splitting tensile strength of at least $4.2 \mathrm{MPa}$, and a chloride penetration resistance of less than $4000 \mathrm{C}$. The slump, air content, compressive strength, splitting tensile strength, flexural strength, and chloride ion permeability of the aggregate-containing concretes were measured. The air-cooled slag aggregates provided the necessary physical and chemical properties and presented no environmental issues. Furthermore, the slump and air content of concrete made with the aggregates met the target values. The slump decreased and the air content increased with increasing amounts of air-cooled slag aggregate. Mechanical testing of the concretes containing air-cooled slag aggregate established that they met the performance requirements for rural road pavement.
\end{abstract}

Keywords: air-cooled slag aggregate; concrete aggregates; mechanical properties; physical properties; rural-road concrete pavement; steel manufacturing byproduct

\section{Introduction}

High-quality natural aggregate for concrete widely used in the construction industry is in short supply, and the use of natural aggregate has been restricted to preserve the environment. Therefore, alternative sources of concrete aggregate that can be supplied sustainably are needed [1,2]. Alternative aggregates include waste-concrete aggregate obtained by crushing waste concrete, and blast-furnace slag aggregate derived from blastfurnace slag generated in the steelmaking process [1-4]. The latter forms as the hightemperature discharge cools, and it is considered environmentally harmless [3-5]. Notably, blast-furnace slags are valuable as alternative concrete aggregates because they have specific gravities that are similar to those of natural aggregates [1,3]. The use of blastfurnace slags aggregates in concrete has been studied since the 1980s [6-10]. Recent studies have focused on using waste slags (granulated water-quenched blast-furnace slags) as admixtures for cement and concrete [11-14]. Research on use of air-cooled slag aggregates in concrete is not extensive, and most commercial applications have used recycled aggregates $[1,15-20])$. These new high-value-added aggregates for concrete offer the potential of lower loadings, and supplement the commonly used low-value-added slag aggregates. [5-7]. Replacing natural aggregates with air-cooled slag aggregates would consume large quantities of industrial byproducts and help the environment [1,15-20]. 
However, to use air-cooled slag aggregates in concrete, certain physical and environmental properties must be present to satisfy the quality and performance requirements of the concrete [1]. Environmental factors, such as soil and groundwater contamination, must also be considered because these industrial byproducts come into contact with groundwater through exposure to rain. Therefore, we report herein the quality and environmental properties of air-cooled slag aggregates in a rural-road paving application [1]. The physical and mechanical properties were analyzed with a view toward improving the manufacturing process, and by extension, the end-use performance.

\section{Materials, Mix Proportions, and Test Methods}

\subsection{Materials}

In this study, we used American Society for Testing and Materials (ASTM) Type 1 cement from Ssangyong Cement Industrial Co., Ltd. (Seoul, Korea). The physical properties and chemical composition of the cement are listed in Table 1. The fly ash used in this study was collected and refined by an electrostatic precipitator from the bituminous coal-fired Dangjin Thermal Power Plant (Dangjin, Korea). Its physical and chemical properties are listed in Table 2. The physical properties and chemical composition of the blast-furnace slag powder used in this study are listed in Table 3. Sea sand (Dangjin, Korea) with a density of $2.62 \mathrm{~g} / \mathrm{mm}^{3}$ was used as the fine aggregate. A cone crusher (Kyoungsung Development Co., Ltd. Dangjin, Korea) was used to produce the air-cooled slag aggregates (Figure 1). The properties of the crushed fine ("GS") and coarse ("GG") aggregates are listed in Tables 4 and 5, respectively. The fine aggregate passed through the $8 \mathrm{~mm}$ sieve and was classified as the aggregate remaining in the $0.08 \mathrm{~mm}$ sieve, and that of the coarse aggregate was classified as aggregate that passed over $90 \%$ of the $25 \mathrm{~mm}$ sieve and remained in the $8 \mathrm{~mm}$ sieve. A polycarboxylic acid-based high-performance water-reducing agent (Dongnam Co., Ltd., Pyeongtaek, Korea) was used; its characteristics are listed in Table 6.

Table 1. Properties of the cement.

\begin{tabular}{|c|c|c|c|c|c|c|c|c|}
\hline \multirow{2}{*}{$\begin{array}{l}\text { Type of } \\
\text { Cement }\end{array}$} & \multirow{2}{*}{$\begin{array}{l}\text { Fineness } \\
\left(\mathrm{cm}^{2} / \mathrm{g}\right)\end{array}$} & \multirow{2}{*}{$\begin{array}{l}\text { Specific } \\
\text { Gravity }\end{array}$} & \multirow{2}{*}{$\begin{array}{l}\text { Stability } \\
(\%)\end{array}$} & \multicolumn{2}{|c|}{ Setting Time } & \multicolumn{3}{|c|}{ Compressive Strength (MPa) } \\
\hline & & & & Initial (min) & Final (min) & 3 Days & 7 Days & 28 Days \\
\hline $\begin{array}{c}\text { Type } 1 \\
\text { Portland }\end{array}$ & 3200 & 3.15 & 0.02 & 220 & 400 & 20.3 & 30.2 & 38.7 \\
\hline
\end{tabular}

Table 2. Physical and chemical properties of the fly ash.

\begin{tabular}{lccccccc}
\hline \multicolumn{2}{c}{ Density $\left(\mathbf{g} / \mathbf{m m}^{\mathbf{3}}\right)$} & \multicolumn{2}{c}{ Fineness $\left(\mathbf{c m}^{\mathbf{2}} \mathbf{g}\right)$} & Absorption & \multicolumn{2}{c}{ L.O.I. * (\%) } \\
\hline \multicolumn{7}{c}{2.14} & \multicolumn{2}{c}{3400} & \multicolumn{2}{c}{0.13} \\
\hline \multicolumn{9}{c}{ Chemical compositions $(\%)$} \\
\hline $\mathrm{SiO}_{2}$ & $\mathrm{Al}_{2} \mathrm{O}_{3}$ & $\mathrm{Fe}_{2} \mathrm{O}_{3}$ & $\mathrm{CaO}$ & $\mathrm{MgO}$ & $\mathrm{Na}_{2} \mathrm{O}$ & $\mathrm{K}_{2} \mathrm{O}$ & $\mathrm{TiO}_{2}$ \\
\hline 58.12 & 23.56 & 7.69 & 2.59 & 1.12 & 0.31 & 1.42 & 1.05 \\
\hline${ }^{*}$ L.O.I.: Loss on ignition.
\end{tabular}

Table 3. Physical and chemical properties of the blast-furnace slag powder.

\begin{tabular}{cccccccc}
\hline & Density $\left(\mathbf{g} / \mathbf{m m}^{3}\right)$ & \multicolumn{3}{c}{ Fineness $\left(\mathbf{c m}^{2} / \mathbf{g}\right)$} & \multicolumn{2}{c}{ L.O.I. (\%) } \\
\hline \multicolumn{7}{c}{2.8} & \multicolumn{3}{c}{$4000 \sim 6000$} \\
\hline \multicolumn{3}{c}{ Chemical composition $(\%)$} \\
\hline $\mathrm{SiO}_{2}$ & $\mathrm{Al}_{2} \mathrm{O}_{3}$ & $\mathrm{Fe}_{2} \mathrm{O}_{3}$ & $\mathrm{CaO}$ & $\mathrm{MgO}$ & $\mathrm{MnO}$ & $\mathrm{TiO}$ & $\mathrm{S}$ \\
\hline 33.1 & 13.9 & 0.29 & 42.4 & 6.1 & 0.4 & 0.96 & 0.66 \\
\hline
\end{tabular}




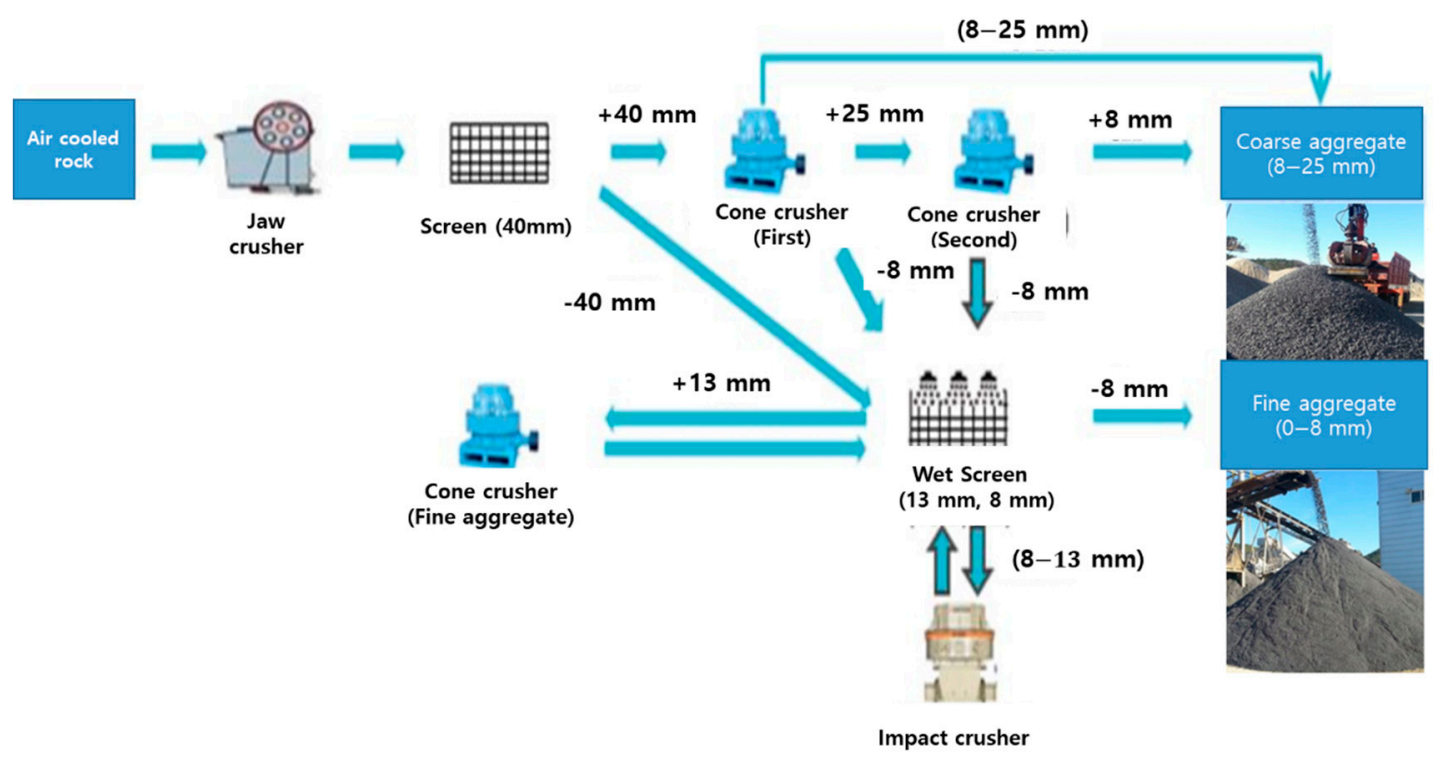

Figure 1. Manufacturing process of air-cooled aggregate for rural-road concrete pavements.

Table 4. Quality test result of the crushed fine aggregate.

\begin{tabular}{cc}
\hline Quality Items & Results \\
\hline Fineness modulus & 2.72 \\
Density $\left(\mathrm{g} / \mathrm{mm}^{3}\right.$ ) & 2.58 \\
Water-absorption ratio (\%) & 1.58 \\
0.08 mm pass efficiency & 6.9 \\
\hline
\end{tabular}

Table 5. Physical properties of the coarse aggregate.

\begin{tabular}{|c|c|c|c|c|c|}
\hline \multirow{2}{*}{ Type of Aggregate } & \multicolumn{3}{|c|}{ Density $\left(\mathrm{g} / \mathrm{mm}^{3}\right)$} & \multirow{2}{*}{ Absorption (\%) } & \multirow{2}{*}{ F.M. } \\
\hline & Bulk & Bulk (SSD) & Apparent & & \\
\hline $\begin{array}{c}\text { Crushed coarse } \\
\text { aggregate }\end{array}$ & 2.80 & 2.65 & 2.83 & 0.35 & 6.92 \\
\hline
\end{tabular}

Table 6. Properties of the polycarboxylic acid-based, high-performance water-reducing agent.

\begin{tabular}{ccccc}
\hline Type & Color & Solids (\%) & Density $\left(\mathbf{g} / \mathbf{m m}^{\mathbf{3}}\right)$ & pH \\
\hline Liquid & Light brown & $\geq 40$ & $1.10 \sim 1.20$ & $4.0 \sim 7.5$ \\
\hline
\end{tabular}

\subsection{Mix Proportions}

The mixing ratio in this study was defined by the ratio of the air-cooled slag coarse and fine aggregates. The target design of concrete using air-cooled slag was based on the design criteria of the Korea Ministry of Agriculture's Agricultural Production Infrastructure Maintenance Business Plan [21] and the Korea Expressway Corporation's Highway Construction Specialized Specifications [22] (Table 7). The results of experiments carried out with different substitution ratios were compared with those for concrete made using only natural aggregate. Tables 8 and 9 list the mixing variables and mixing ratios used, respectively, and the coding used to identify the various samples. The concrete was mixed as follows: aggregates and cement were injected into a fan-type forced mixer and drymixed for $1.5 \mathrm{~min}$, after which water and the polycarboxylic acid water-reducing agent were added to the mixer; mixing was continued for $2 \mathrm{~min}$. 
Table 7. Target performance of the rural-road pavement using air-cooled slag aggregate $[1,21,22]$.

\begin{tabular}{ccc}
\hline Properties & Unit & Target Performance \\
\hline Slump & $\mathrm{Mm}$ & $\geq 80 \mathrm{~mm}$ \\
Air contents & $\%$ & $4.5 \pm 1.5$ \\
Compressive strength & $\mathrm{MPa}$ & $\geq 21$ \\
Splitting tensile strength & $\mathrm{MPa}$ & $\geq 4.2$ \\
Flexural strength & $\mathrm{MPa}$ & $\geq 4.5$ \\
Repeated freezing and thawing cycles & $\%$ & $\geq 80 \%$ \\
(relative mechanical modulus) & $\% 4000$ \\
Chloride ion penetration & Coulombs & $<$ \\
\hline
\end{tabular}

Table 8. Rural-road pavement concrete mixing test plan.

\begin{tabular}{ccc}
\hline \multirow{2}{*}{ Item } & \multicolumn{2}{c}{ Replacement Ratio of Air-Cooled Slag Aggregate } \\
\cline { 2 - 3 } & Coarse Aggregate & Fine Aggregate \\
\hline Plain & $0 \%$ & $0 \%$ \\
GS 50\% & $0 \%$ & $50 \%$ \\
GG 50\% & $50 \%$ & $0 \%$ \\
GG $100 \%$ & $100 \%$ & $0 \%$ \\
GS 50\%/GG 100\% & $100 \%$ & $50 \%$ \\
\hline
\end{tabular}

Table 9. Mix proportion of the rural-road pavement concrete.

\begin{tabular}{|c|c|c|c|c|c|c|c|c|c|c|c|c|}
\hline \multirow{2}{*}{ Type of Mix } & \multirow{2}{*}{$\begin{array}{c}\text { W/B } \\
(\%)\end{array}$} & \multirow{2}{*}{$\begin{array}{l}\text { S/a } \\
(\%)\end{array}$} & \multicolumn{10}{|c|}{ Unit Weight $\left(\mathrm{kg} / \mathrm{m}^{3}\right)$} \\
\hline & & & $\mathbf{W}$ & $\mathrm{C}$ & BFS & FA & CS & SS & GS & G & GG & $\mathrm{AD}$ \\
\hline Plain & & & 161 & 173 & 73 & 44 & 458 & 452 & - & 926 & - & 2.03 \\
\hline GS 50\% & & & 161 & 173 & 73 & 44 & 229 & 226 & 455 & 926 & - & 2.03 \\
\hline GG 50\% & 55.5 & 49.6 & 161 & 173 & 73 & 44 & 458 & 452 & - & 463 & 463 & 2.03 \\
\hline GG $100 \%$ & & & 161 & 173 & 73 & 44 & 458 & 452 & - & - & 926 & 2.03 \\
\hline $\begin{array}{c}\text { GS } 50 \% / G G \\
100 \%\end{array}$ & & & 161 & 173 & 73 & 44 & 229 & 226 & 455 & - & 926 & 2.03 \\
\hline
\end{tabular}

\subsection{Test Methods}

\subsubsection{Physical Properties of the Air-Cooled Slag Aggregates}

The physical and chemical properties of the air-cooled slag aggregates were assessed for chemical composition, density, absorption rate, unit volume weight, and particle size according to the KS F 2527 standard [23].

\subsubsection{Environmental-Hazard Testing of the Air-Cooled Slag Aggregates}

The environmental hazards were assessed according to the Waste Management Act of the Ministry of Environment of the Republic of Korea [24] and the Japanese standard JIS K 0058 [25].

\subsubsection{Slump Value and Air Content}

The slump test was conducted according to the ASTM C143 "Standard Test Method for Slump of Hydraulic-Cement Concrete" [26]. The air content was determined according to the ASTM C231/C231M "Standard Test Method for Air Content of Freshly Mixed Concrete by the Pressure Method" [27].

\subsubsection{Compressive Strength}

Compressive strength was measured according to the ASTM C39/C39M "Standard Test Method for Compressive Strength of Cylindrical Concrete Specimens" [28]. A test specimen with a diameter of $100 \mathrm{~mm}$ and height of $200 \mathrm{~mm}$ was made and cured at 
$23 \pm 2{ }^{\circ} \mathrm{C}$ and $58 \%$ relative humidity for $24 \mathrm{~h}$. The form was removed 1 day later, and the specimen was then water-cured at $23 \pm 2{ }^{\circ} \mathrm{C}$ for 28 days.

\subsubsection{Flexural Strength}

The flexural strength was measured according to the ASTM C78/C78M "Standard Test Method for Flexural Strength of Concrete (Using Simple Beam with Third-Point Loading)" [29]. A $100 \times 100 \times 400 \mathrm{~mm}^{3}$ test specimen of the square-post type was made and cured at $23 \pm 2{ }^{\circ} \mathrm{C}$ and $58 \%$ relative humidity for $24 \mathrm{~h}$. The form was then removed, and the specimen was water-cured at $23 \pm 2{ }^{\circ} \mathrm{C}$.

\subsubsection{Splitting Tensile Strength}

The splitting tensile strength was measured according to the ASTM C496/C496M "Standard Test Method for Splitting Tensile Strength of Cylindrical Concrete Specimens" [30]. A test specimen with a diameter of $100 \mathrm{~mm}$ and height of $200 \mathrm{~mm}$ was made and cured at $23 \pm 2{ }^{\circ} \mathrm{C}$ and $58 \%$ relative humidity for $24 \mathrm{~h}$. The form was then removed, and the specimen was water-cured for 28 days at $23 \pm 2{ }^{\circ} \mathrm{C}$.

\subsubsection{Chloride Ion Penetration}

The chlorine ion penetration resistance test was performed as follows. A test specimen with a diameter of $100 \mathrm{~mm}$ and height of $200 \mathrm{~mm}$ was made and cured at $23 \pm 2{ }^{\circ} \mathrm{C}$ and $58 \%$ relative humidity for $24 \mathrm{~h}$; then, the form was removed, and the specimen was water-cured at $23 \pm 2{ }^{\circ} \mathrm{C}$ for 28 days. After curing, the specimens were cut to a height of $50 \mathrm{~mm}$. The cut specimens were placed in a vacuum desiccator and maintained under vacuum for $3 \mathrm{~h}$. The desiccator was then opened, the specimens were immersed in distilled water, and the vacuum was reapplied for another hour. The specimens were then removed from the desiccator. Each specimen was mounted onto the test cell filled with $3.0 \% \mathrm{NaCl}$ solution on one side and $0.3 \% \mathrm{NaOH}$ solution on the other side. Testing was done according to the ASTM C1202 "Standard Test Method for Electrical Indication of Concrete's Ability to Resist Chloride Ion Penetration" [31].

\section{Results}

\subsection{Physical Properties of the Air-Cooled Slag Aggregates}

The physical and chemical test results of the air-cooled slag aggregates established that they satisfied the quality metrics of blast-furnace slag aggregate required by the KS standards. The chemical composition was $40.81 \% \mathrm{CaO}, 0.78 \% \mathrm{~S}, 0.39 \% \mathrm{SO}_{3}$, and $1.19 \%$ $\mathrm{FeO}$, which all met the requirements of the KS standards of less than $45 \%, 2.0 \%, 0.5 \%$, and $3.0 \%$, respectively. Furthermore, the air-cooled slag fine aggregates had a density of $2.77 \mathrm{~g} / \mathrm{cm}^{3}$, an absorption rate of $1.57 \%$, and a unit volume mass of $1.70 \mathrm{~kg} / \mathrm{L}$, which all satisfied the requirements of over $2.5 \mathrm{~g} / \mathrm{cm}^{3}$, less than $3.5 \%$, and over $1.45 \mathrm{~kg} / \mathrm{L}$, respectively. Tables 10 and 11 list the physical properties of the fine and coarse air-cooled slag aggregates.

Table 10. Properties of the air-cooled slag fine aggregate.

\begin{tabular}{cccccccc}
\hline \multirow{2}{*}{ Item } & \multicolumn{4}{c}{ Component (\%) } & \multicolumn{3}{c}{ Fine Aggregate } \\
\cline { 2 - 8 } & $\mathrm{CaO}$ & $\mathbf{S}$ & $\mathrm{SO}_{3}$ & $\mathrm{FeO}$ & Absolute Dry Density & Water Absorption Ratio & Unit Volume Weight \\
\hline Value & 40.81 & 0.00 & 0.39 & 1.19 & 2.77 & 1.57 & 1.70 \\
\hline
\end{tabular}

Table 11. Properties of the air-cooled slag coarse aggregate.

\begin{tabular}{cccccccc}
\hline \multirow{2}{*}{ Item } & \multicolumn{4}{c}{ Component (\%) } & \multicolumn{2}{c}{ Coarse Aggregate } \\
\cline { 2 - 8 } & $\mathrm{CaO}$ & $\mathbf{S}$ & $\mathrm{SO}_{3}$ & $\mathrm{FeO}$ & Absolute Dry Density & Water Absorption Ratio & Unit Volume Weight \\
\hline Value & 40.81 & 0.00 & 0.39 & 1.19 & 2.49 & 4.28 & 1.41 \\
\hline
\end{tabular}




\subsection{Environmental-Hazard Testing of the Air-Cooled Slag Aggregates}

The air-cooled slag aggregates and concrete made with them satisfied all of the criteria of the Korean waste elution test (Table 12). The concentrations of seven elements in the eluate, including $\mathrm{Pb}$ and $\mathrm{Cu}$, were below the maximum allowable levels. The air-cooled slag aggregates yielded undetectable amounts of $\mathrm{Pb}, \mathrm{As}, \mathrm{Hg}, \mathrm{Cd}$, and $\mathrm{Cr}^{+6}$. Copper and $\mathrm{CN}$ concentrations were 0.0012 and $0.0025 \mathrm{mg} / \mathrm{L}$, respectively, which easily satisfied the maximum allowable limits of 3 and $1 \mathrm{mg} / \mathrm{L}$, respectively. Concrete containing the aircooled slags yielded undetectable levels of $\mathrm{As}, \mathrm{Hg}, \mathrm{Cd}$, and $\mathrm{Cr}^{+6}$, and only $0.020,0.004$, and $0.003 \mathrm{mg} / \mathrm{L}$ of $\mathrm{Pb}, \mathrm{Cu}$, and $\mathrm{CN}$, respectively, which satisfied the maximum allowable limits of 3, 3, and $1 \mathrm{mg} / \mathrm{L}$. The measurable level of $\mathrm{Pb}$ extracted from the concrete containing the air-cooled slags was attributed to $\mathrm{Pb}$ contained in the other materials used in preparing the cement; i.e., the water and admixture. Conventional concrete made with natural aggregates yielded undetectable levels of all species except $\mathrm{Cu}$ and $\mathrm{CN}$, which were detected at 0.0014 and $0.003 \mathrm{mg} / \mathrm{L}$, respectively. Nevertheless, these levels easily satisfied the maximum allowable amounts. The elution volumes were slightly greater for concrete made with the air-cooled slag aggregates, but were well within the regulatory limits for all of the analyzed species. This testing established that both the air-cooled slag aggregates and concrete made with them met the environmental hazards requirements. Hence, air-cooled slag aggregates are suitable for use as concrete aggregate from the perspective of resource recycling. The results of testing according to the Japanese JIS K 0058 standard [25] are given in Table 13. The air-cooled slag aggregates gave the following results for $\mathrm{Cd}$, As, Se, F, and B: $0.0923,0.3,3.633,107.17$, and $68.61 \mathrm{mg} / \mathrm{kg}$, respectively, and which satisfied the respective maximum allowable limits value of all the test items. $\mathrm{Pb}, \mathrm{Cr}^{+6}$ and $\mathrm{Hg}$ were not detected. The air-cooled slag aggregates yielded elution volumes of 1.287, 1.330, not detected, 0.333, 0.133, 1.203, 143.937, and $35.69 \mathrm{mg} / \mathrm{kg}$ for $\mathrm{Cd}, \mathrm{Pb}, \mathrm{Cr}^{+6}, \mathrm{As}, \mathrm{Hg}$, Se, F, and $\mathrm{B}$, respectively. Although $\mathrm{Pb}$ and $\mathrm{Hg}$ were detected, their elution volumes were within the normal range, and their detectable amounts were attributed to the cement admixture. The elution volumes of heavy metals from conventional concrete made with natural aggregates were 1.65, 10.033, not detected, 1.227, 0.013, 3.967, 189.647, and $36.53 \mathrm{mg} / \mathrm{kg}$ for $\mathrm{Cd}, \mathrm{Pb}$, $\mathrm{Cr}^{+6}, \mathrm{As}, \mathrm{Hg}, \mathrm{Se}, \mathrm{F}$, and $\mathrm{B}$, respectively. The elution volume of the concrete made with aircooled slag aggregates was less than that of the concrete made with the natural aggregate.

Table 12. Hazardous-substance content analysis results according to JIS K 0058 (unit: mg/kg).

\begin{tabular}{ccccccccc}
\hline Item & $\mathbf{C d}$ & $\mathbf{P b}$ & $\mathbf{C r}^{+\mathbf{6}}$ & $\mathbf{A s}$ & $\mathbf{H g}$ & $\mathbf{S e}$ & $\mathbf{F}$ & $\mathbf{B}$ \\
\hline Elution standard & 150 & 150 & 250 & 150 & 15 & 150 & 4000 & 4000 \\
Value & 0.9233 & $\mathrm{ND}$ & $\mathrm{ND}$ & 0.3 & $\mathrm{ND}$ & 3.633 & 107.17 & 68.61 \\
\hline
\end{tabular}

Table 13. Results of heavy-metal leaching test according to the waste-management law (unit: $\mathrm{mg} / \mathrm{L}$ ).

\begin{tabular}{cccccccc}
\hline Item & $\mathbf{P b}$ & $\mathbf{C u}$ & $\mathbf{A s}$ & $\mathbf{H g}$ & $\mathbf{C d}$ & $\mathbf{C r}^{+\mathbf{6}}$ & $\mathbf{C N}$ \\
\hline Elution standard & 3 & 3 & 1.5 & 0.005 & 0.3 & 1.5 & 1 \\
Value & $\mathrm{ND}$ & 0.0012 & $\mathrm{ND}$ & $\mathrm{ND}$ & $\mathrm{ND}$ & $\mathrm{ND}$ & 0.0025 \\
\hline
\end{tabular}

\subsection{Slump Values and Air Contents}

The slump test results for the rural-road pavement concrete made with the air-cooled slag aggregates are shown in Figure 2. The slump value decreased with increasing aircooled slag aggregate content, from 97.25 for the Plain to $94.25,90.25,87.00$, and $85.25 \mathrm{~mm}$ for the GS 50\%, GG 50\%, GG 100\%, and GS 50\%/GG 100\% mixes, respectively. The reduction in slump value was due to greater water absorption by the air-cooled slag aggregates because of their greater surface porosity. Not surprisingly, mixes containing the coarse air-cooled slag aggregate returned higher slump values than the corresponding mixes made with the fine aggregate. The air-content ratio was used to evaluate the effect of substitution ratio of the air-cooled slag aggregates on slump. The Plain, GS 50\%, GG 50\%, 
GG 100\%, and GS 50\%/GG 100\% mixes had slump values of 1.00, 0.97, 0.93, 0.89, and 0.88, respectively. It was evident that the slump value decreased with an increasing substitution ratio of the air-cooled slag aggregates. The GS 50\%/GG 100\% mix gave the greatest reduction (12\%) compared with the Plain mix. The slump value affects workability, and an appropriate amount of slump is necessary in the field. Our target minimum slump value of $80 \mathrm{~mm}$ was satisfied by all of the mixes, and so we do not expect any workability issues with use of these mixes in field applications of rural-road pavement concrete containing air-cooled slag aggregates. Figure 3 shows the air-content test results for the rural-road pavement concrete. The air content increased with increasing air-cooled slag aggregate fraction, as follows: from 4.66 for the Plain to 4.86, 5.03, 5.27, and 5.39\% for the GS 50\%, GG 50\%, GG 100\%, and GS 50\%/GG 100\% mixes, respectively (Figure 3a). This trend was attributed to the greater surface porosity of the air-cooled slag aggregates. Additionally, the values for mixes containing the coarse air-cooled slag aggregate were much higher than those of the corresponding mixes made with the fine aggregate. This result was attributed to the coarse aggregate having a greater surface porosity than the fine aggregate. The air content for all of the test mixes satisfied this requirement. The air-content ratio was defined as the ratio of the air content of the mix containing an air-cooled slag aggregate to that of the Plain mix containing conventional aggregate. The Plain, GS 50\%, GG 50\%, GG $100 \%$, and GS 50\%/GG 100\% samples had air content ratios of 1.00,1.04,1.08, 1.13, and 1.16 , respectively (Figure $3 b$ ). The presence of air-cooled slag aggregates increased the air content relative to the Plain mix.

\subsection{Compressive Strength}

Figure 4 shows the results of the compressive-strength test for the rural-road pavement concrete containing the air-cooled slag aggregates. The compressive strengths were 27.16, 26.48, 26.36, 25.60, and 25.43 MPa for the Plain, GS 50\%, GG 50\%, GG 100\%, and GS 50\%/GG $100 \%$ mixes, respectively, showing a decreasing value with an increasing substitution ratio of the coarse or fine air-cooled slag aggregates. This behavior was attributed to the higher surface porosity of the air-cooled slag aggregates compared with the conventional aggregate. All of the mixes met the design criterion of $21 \mathrm{MPa}$. The compressive strength ratios of the Plain, GS 50\%, GG 50\%, GG 100\%, and GS 50\%/GG 100\% samples were 1.00, $0.97,0.97,0.94$, and 0.94 , respectively. It was evident that incorporating the air-cooled slag aggregates decreased the compressive strength relative to the Plain mix. As noted above, the GS 50\%/GG 100\% combination had an air content that was $6 \%$ lower than that of the Plain mix. It was established that a $1 \%$ increase in air content led to a $4-6 \%$ lower compressive strength [32]. Therefore, the trend in compressive strength was not surprising. However, the absolute reduction in compressive strength was not as large as expected; i.e., $10 \%$ or less, which was attributed to the presence of fly ash and blast-furnace slag powder that filled some pores [33]. The compressive strengths of all of the mixes exceeded the design value, so we do not expect any issues regarding this property in the field. 


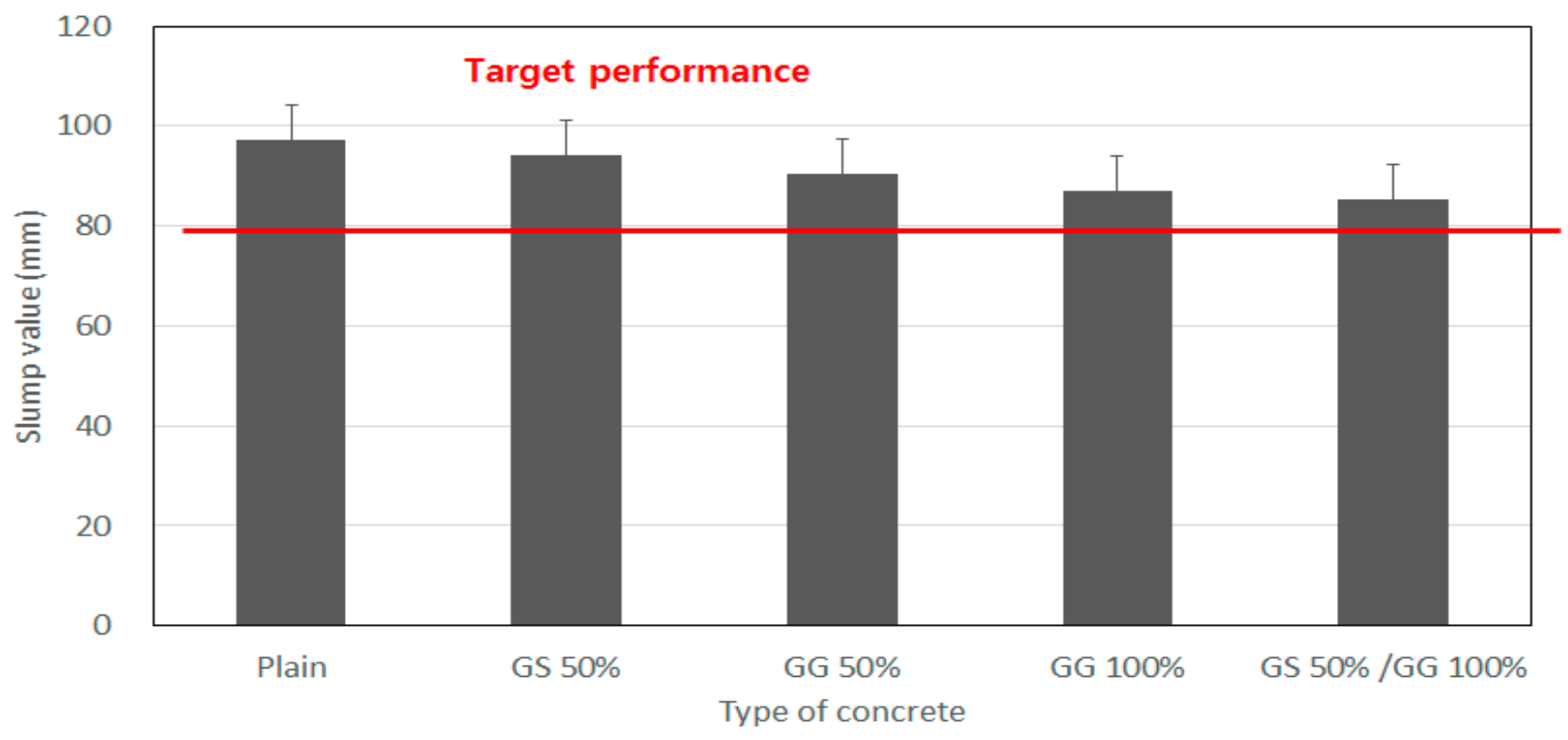

(a) Slump values.

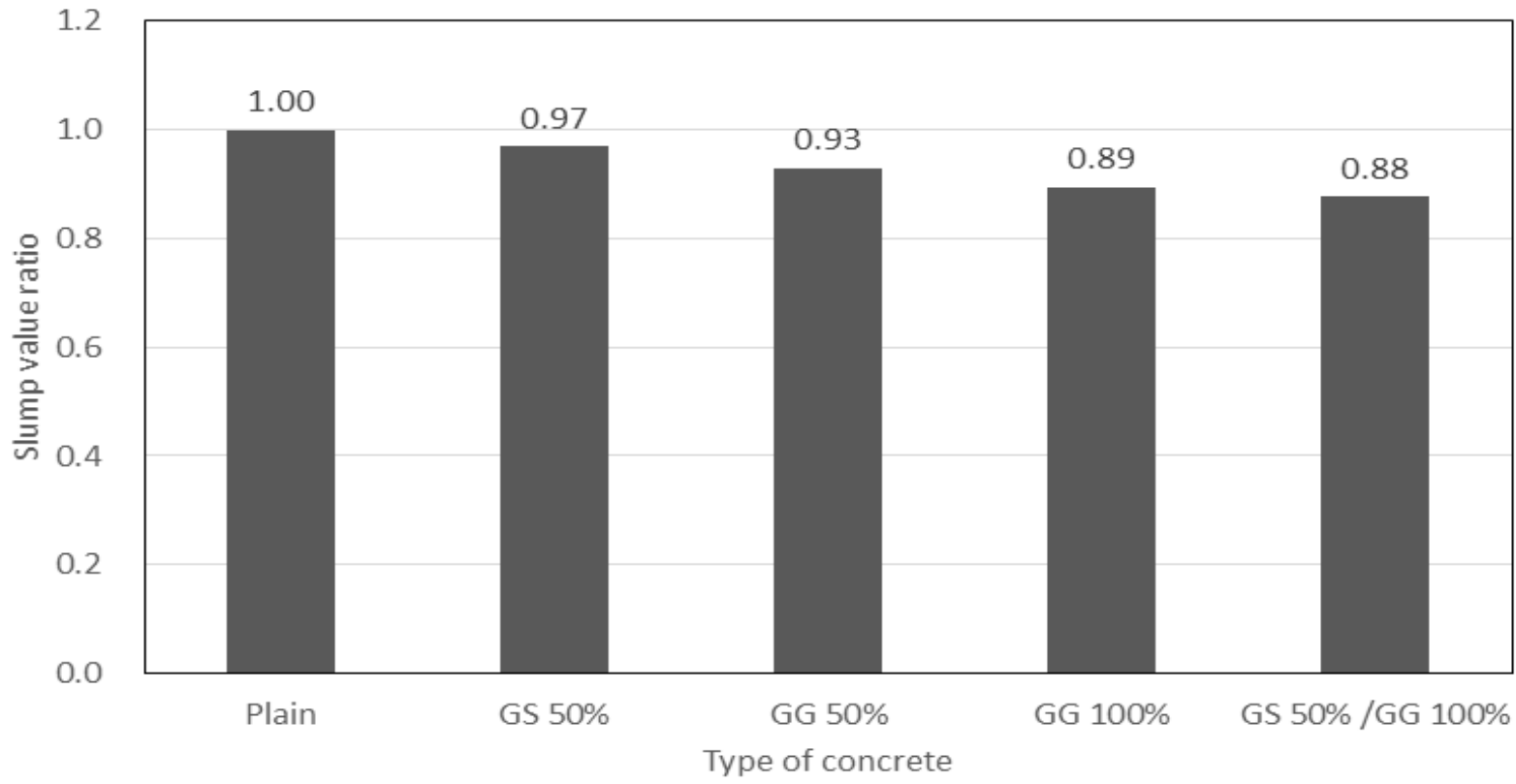

(b) Slump value ratios.

Figure 2. Slump test results. 


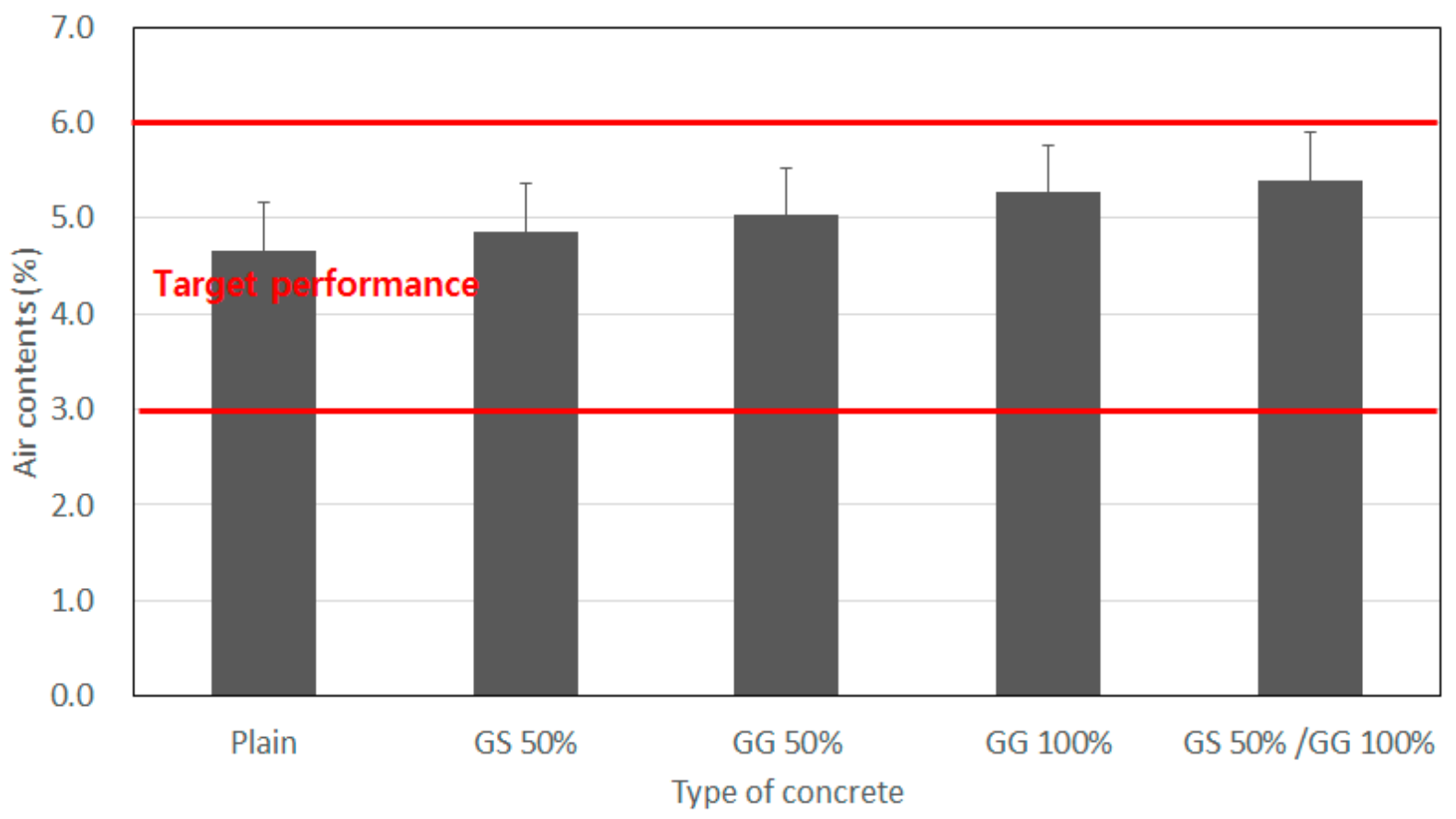

(a) Air-content values.

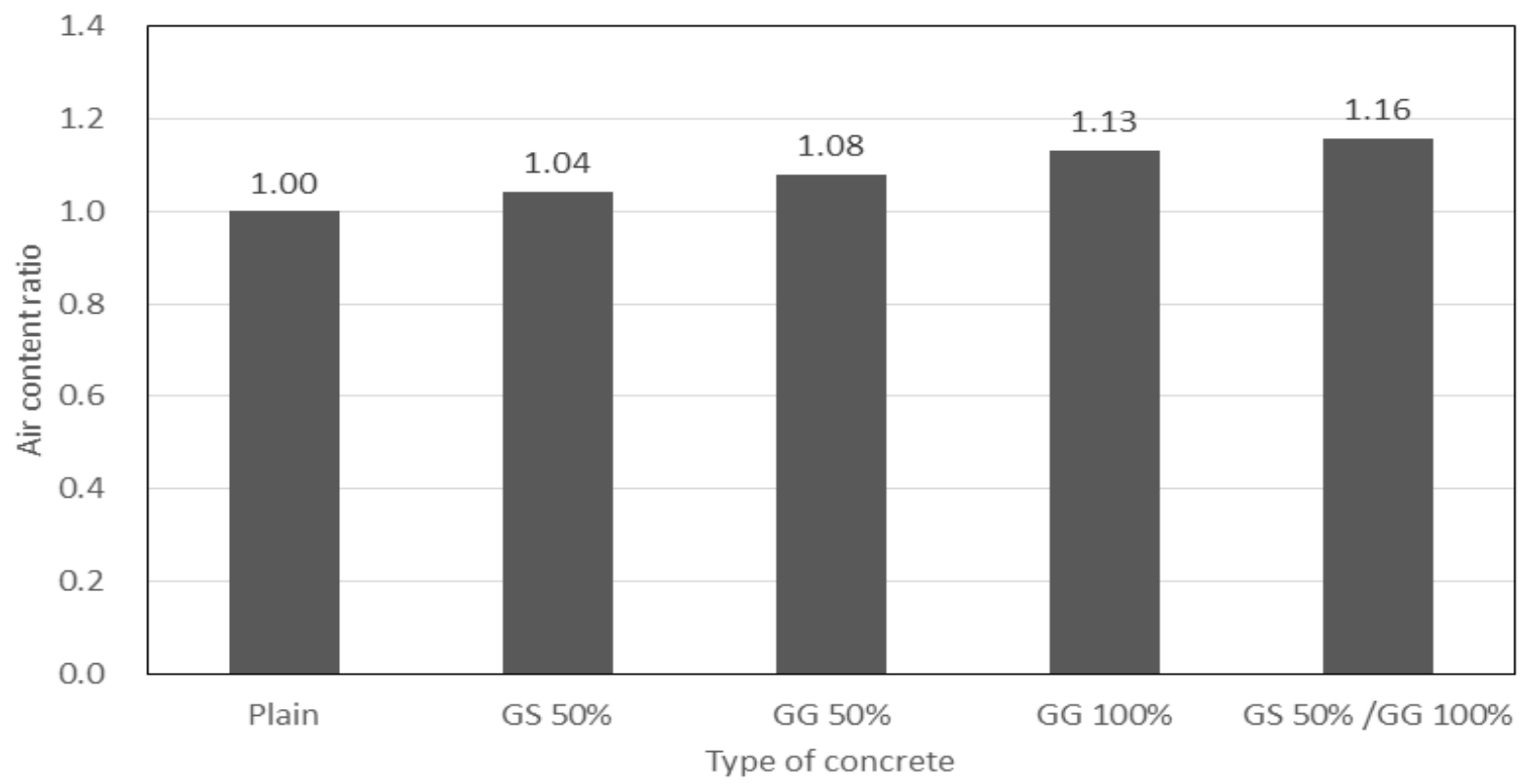

(b) Air-content ratios.

Figure 3. Air-content test results. 


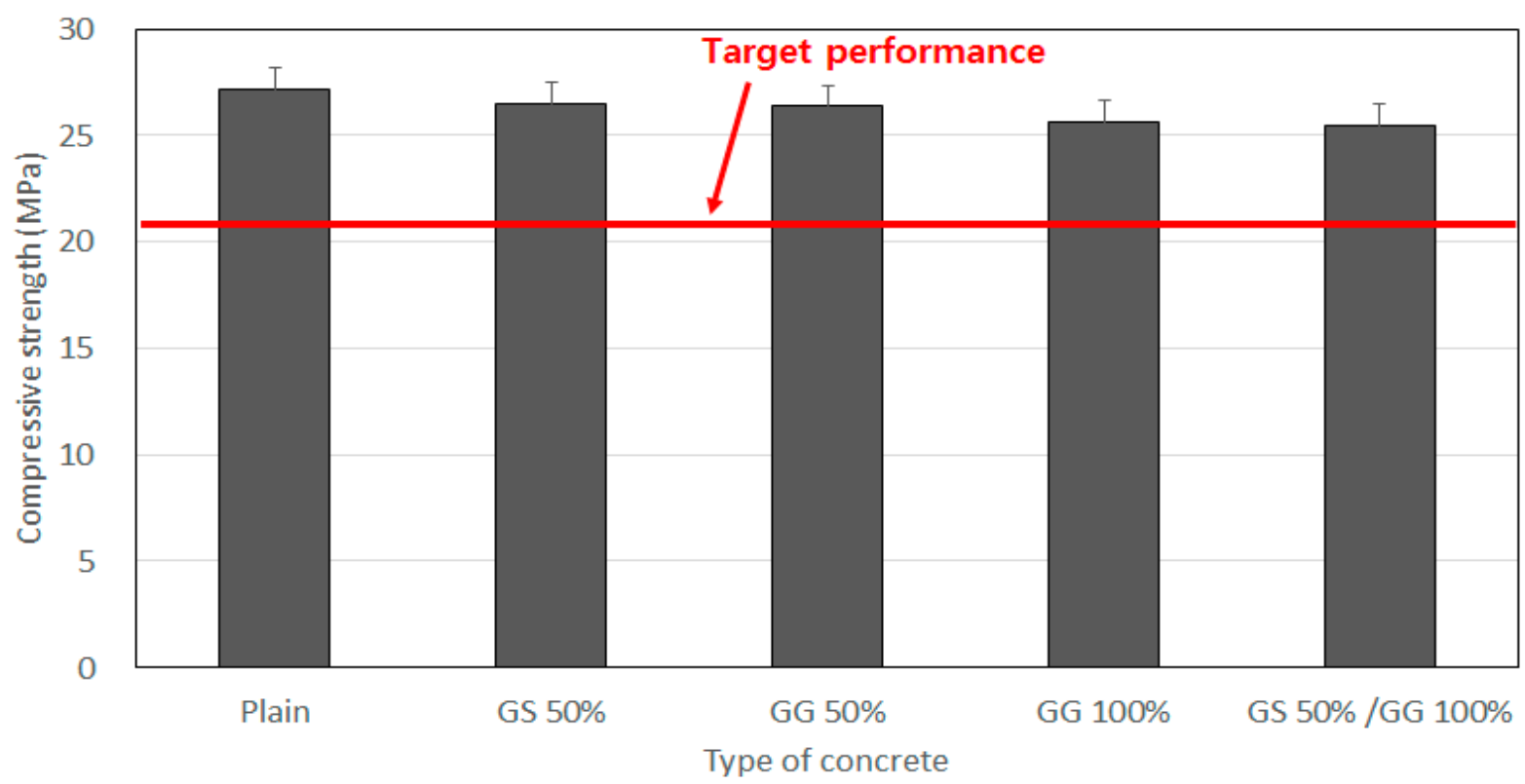

(a) Compressive strengths.

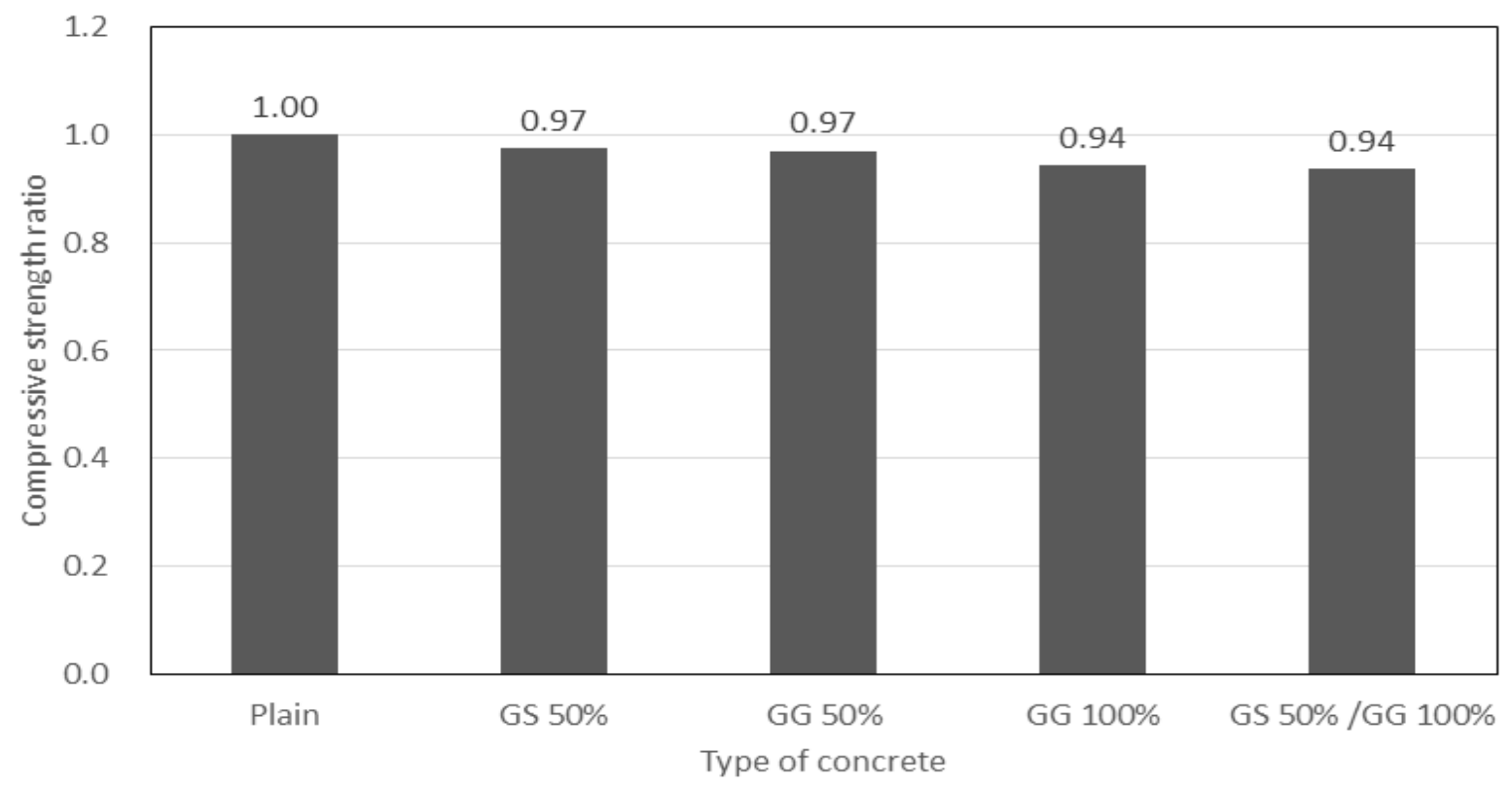

(b) Compressive-strength ratios.

Figure 4. Test results for compressive strength.

\subsection{Flexural Strength}

Figure 5 shows the results of flexural-strength testing for the rural-road pavement concrete mixes containing the air-cooled slag aggregates. This property decreased with increasing amounts of air-cooled slag aggregate, following the same trend as that for the compressive strength. The measured compressive strengths for the Plain, GS 50\%, GG 50\%, GG $100 \%$, and GS $50 \% / \mathrm{GG} 100 \%$ mixes were $5.69,5.28,4.98,4.88$, and $4.80 \mathrm{MPa}$, respectively. 


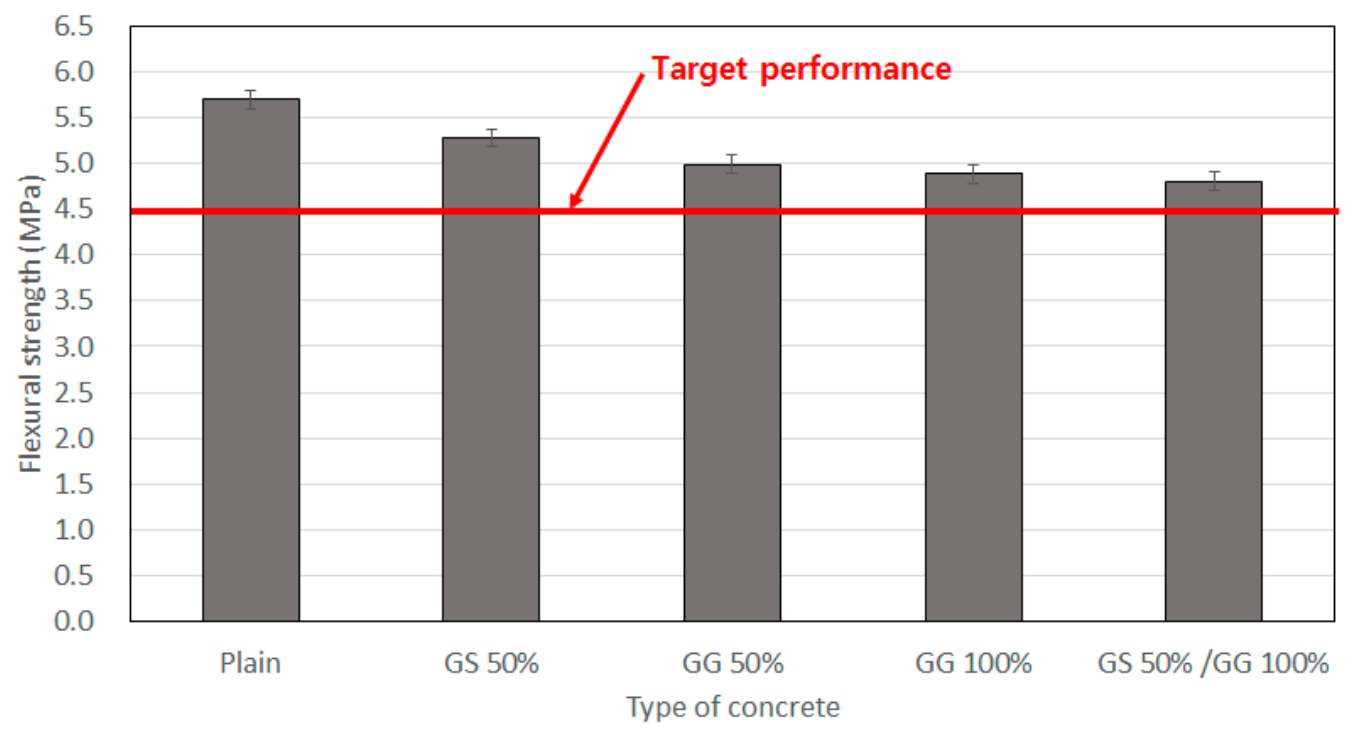

(a) Flexural strengths.

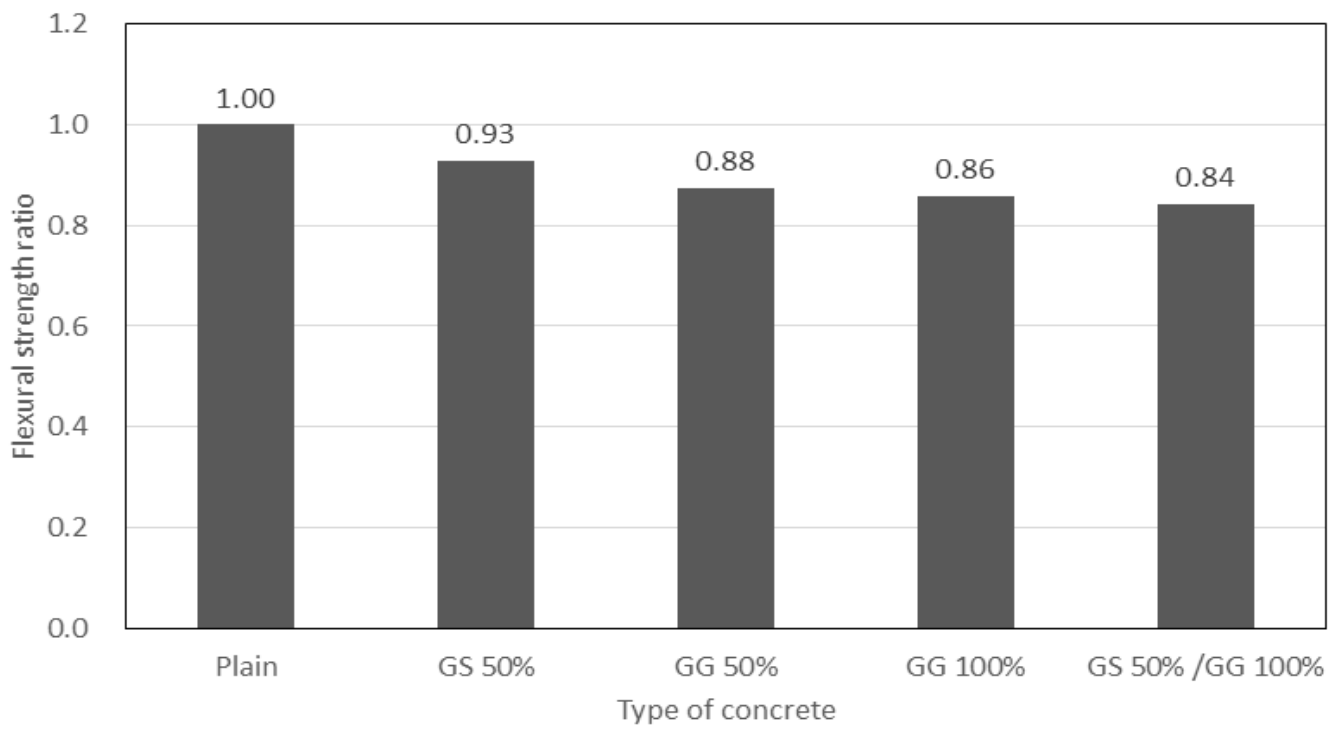

(b) Flexural-strength ratios.

Figure 5. Test results for flexural strength.

The flexural strength ratios of the Plain, GS 50\%, GG 50\%, GG 100\%, and GS 50\%/GG $100 \%$ mixes were $1.00,0.93,0.88,0.86$, and 0.84 , respectively. The value for the GS $50 \% / G G$ $100 \%$ combination was $16 \%$ lower than that of the Plain mix, which was attributed to the higher porosity of the experimental mixes. We adopted a flexural-strength design target of 4.5 MPa, which is the quality standard of the Korea Expressway Corporation's Highway Specialized Specifications [22]. All of our mixes met the design target. The fly ash and blast-furnace slag powder present in the mixes effectively filled the pores generated by the addition of the air-cooled slag aggregates [34]. The flexural strengths of all of the mixes exceeded the design value, so we do not expect any issues regarding this property in the field.

\subsection{Splitting Tensile Strength}

Figure 6 shows the results of the splitting tensile strength test for the various mixes. This property decreased with increasing air-cooled slag aggregate content. The values for the Plain, GS 50\%, GG 50\%, GG 100\%, and GS 50\%/GG 100\% samples were 4.53, 4.48, 4.37, 
4.32 , and 4.27 $\mathrm{MPa}$, respectively. The splitting tensile strength ratios of the Plain, GS 50\%, GG 50\%, GG 100\%, and GS 50\%/GG 100\% samples were 1.00, 0.99, 0.96, 0.95, and 0.94, respectively. Incorporating air-cooled slag aggregates clearly decreased the splitting tensile strength relative to the Plain mix. As noted above, the GS 50\%/GG 100\% combination had an air content that was 6\% lower than that of the Plain mix. Although the large pores introduced by the air-cooled slag aggregates decreased the tensile strength, the reduction was less than $10 \%$. This was because the fly ash and blast-furnace slag powder present in the mix filled the pores of the concrete generated by the introduction of the air-cooled slag aggregates [33,34]. We adopted a design target value of 4.2 MPa for the splitting tensile strength, which is the Korea Expressway Corporation's quality standard for highway pavement concrete. The splitting tensile strength of all of our mixes satisfied this standard. Therefore, we do not anticipate any issues in the field from the perspective of splitting tensile strength.

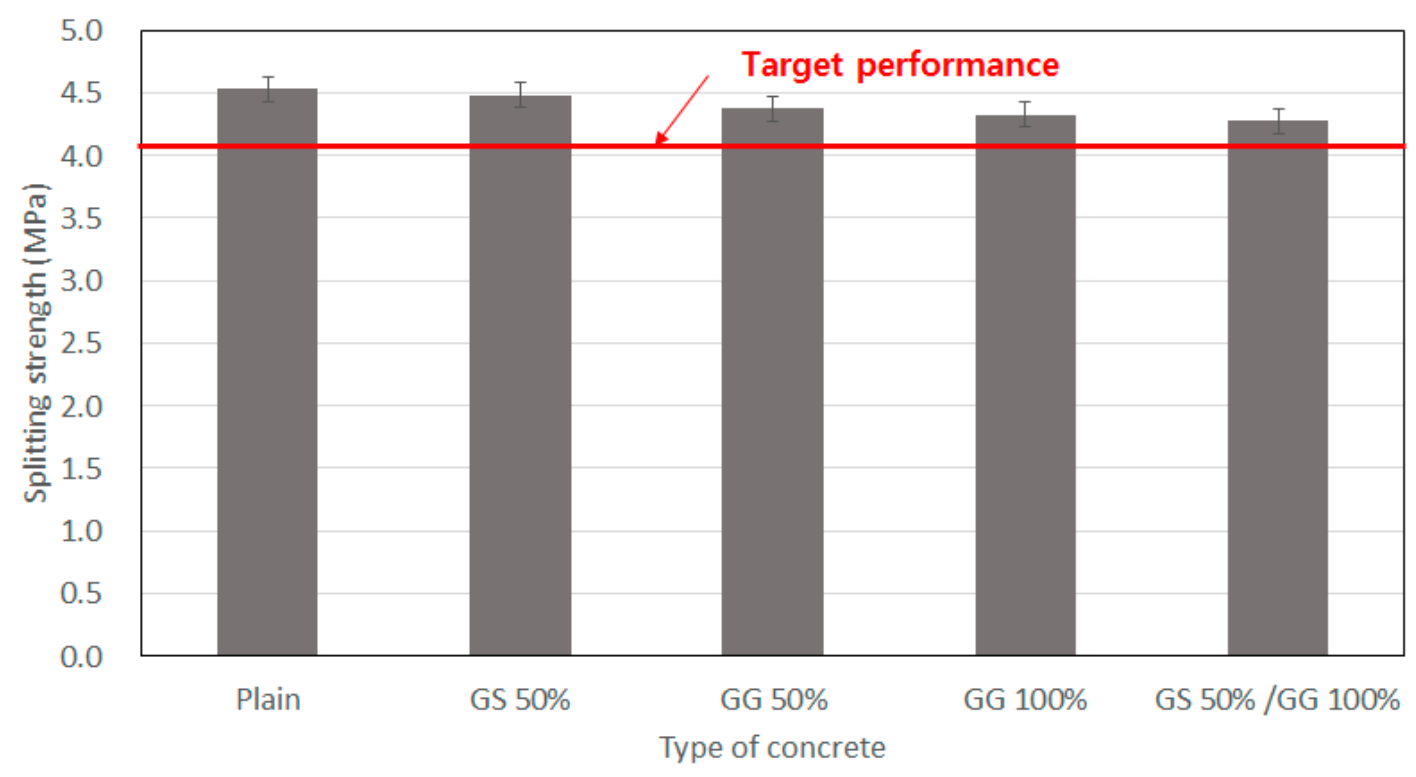

(a) Splitting tensile strengths.

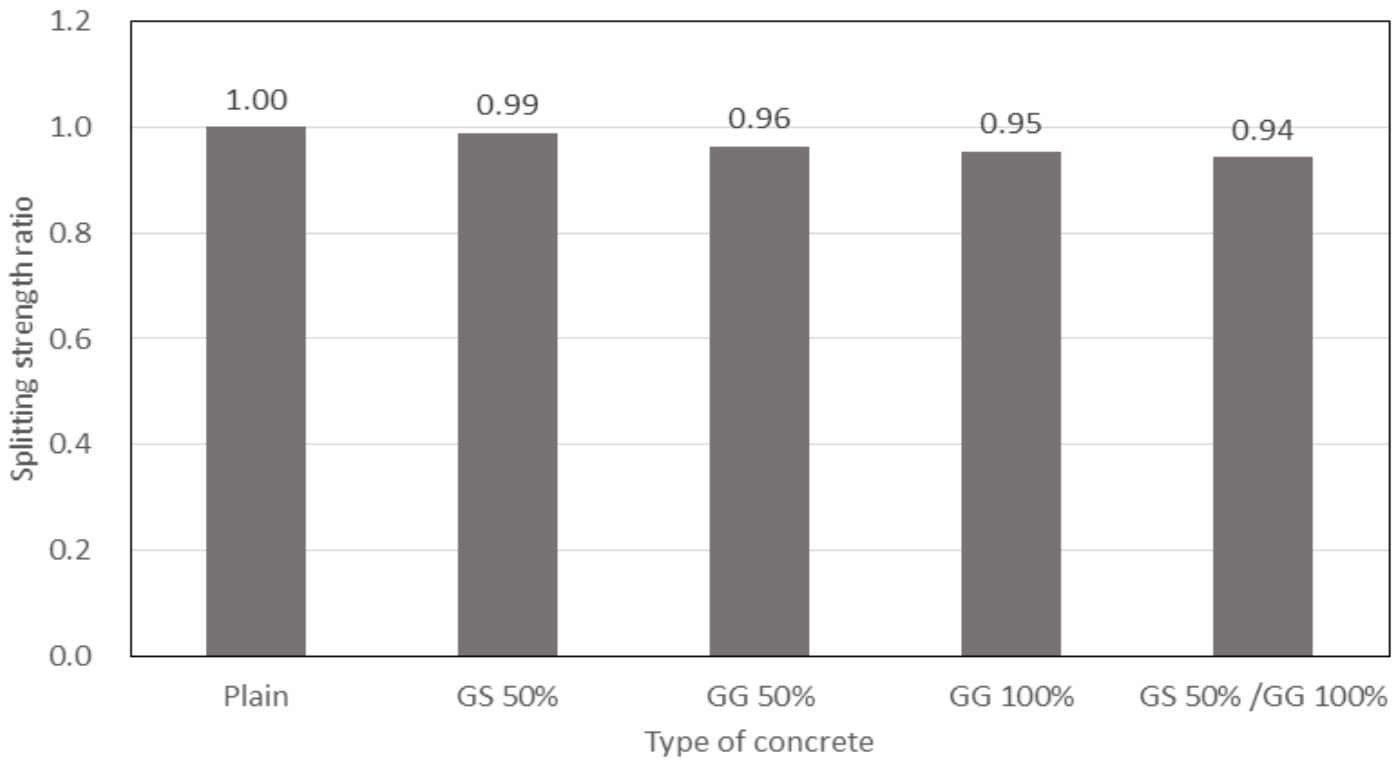

(b) Splitting tensile strength ratios.

Figure 6. Test results for splitting tensile strength. 


\subsection{Chloride Ion Penetration}

Figure 7 shows the results of chloride ion permeability testing. The targeted permeability of $4000 \mathrm{C}$ or less was satisfied by all of the mixes. The values for the Plain, GS $50 \%$, GG 50\%, GG 100\%, and GS 50\%/GG 100\% mixes were 3483, 3458, 3351, 3421, and $3232 \mathrm{C}$, respectively. The permeability increased with an increasing amount of air-cooled slag aggregate.

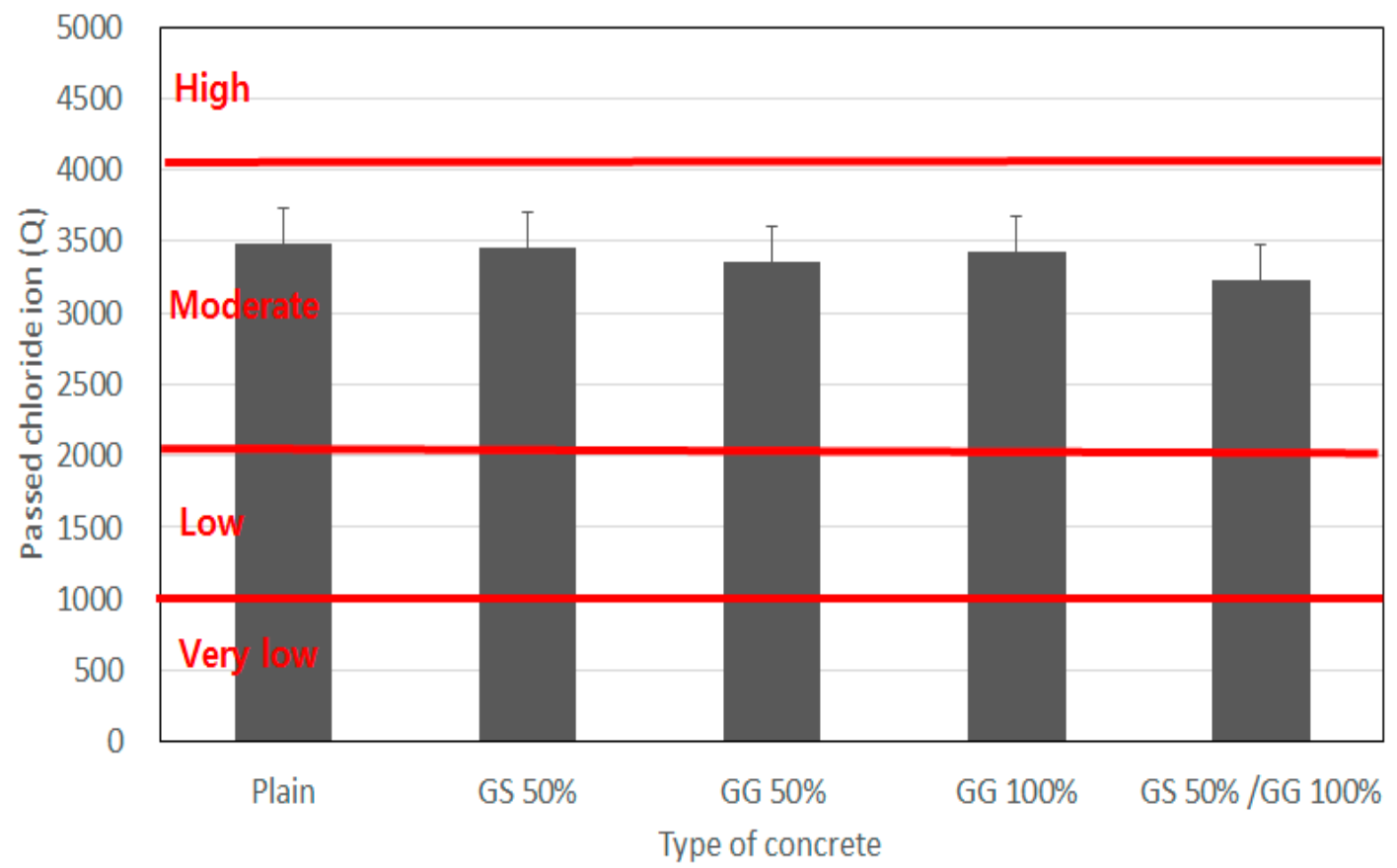

(a) Chloride ion penetration values.

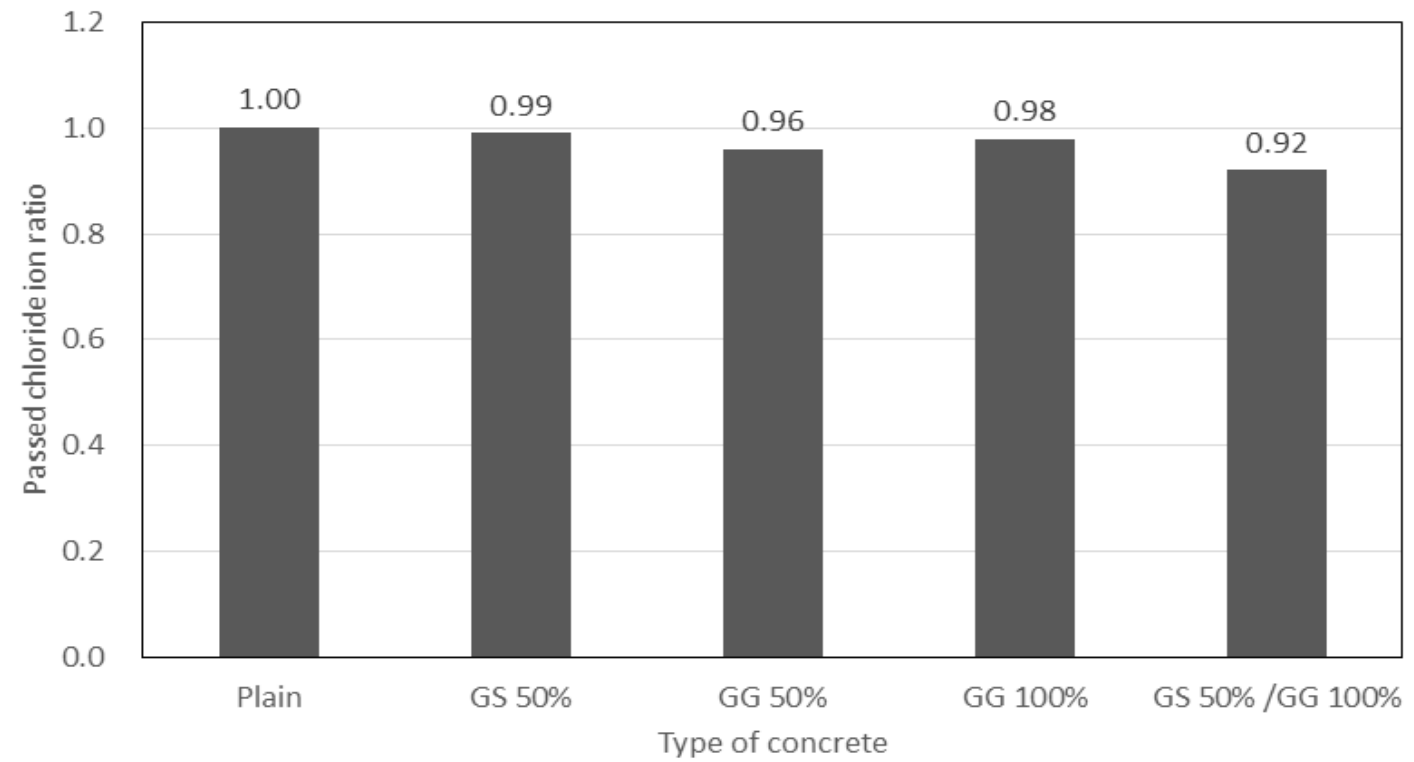

(b) Chloride ion penetration ratios.

Figure 7. Test results for chloride ion penetration.

The chlorine ion permeability ratios for the Plain, GS 50\%, GG 50\%, GG 100\%, and GS 50\%/GG 100\% samples were 1.00, 0.99, 0.96, 0.98, and 0.92, respectively. Relative to the Plain mix, mixes that contained air-cooled slag aggregates had lower chloride ion permeabilities. The fly ash and blast-furnace slag powder in all of the mixes filled the 
micropores present in the air-cooled slag aggregates and concrete. The GS 50\%/GG 100\% composition had an air content that was $8 \%$ lower than that of the Plain mix, which was consistent with such pore filling. The chlorine ion permeabilities of the experimental samples all met the $4000 \mathrm{C}$ maximum design criterion. Therefore, we do not anticipate any issues in the field concerning chloride ion permeability.

\section{Conclusions}

This study was conducted to establish the utility of air-cooled slag aggregate, which is an underutilized byproduct of the steel industry, as an aggregate for concrete. The aircooled slag manufacturing process was analyzed and adjusted to produce aggregates with appropriate physical properties. Rural-road pavement concrete containing these aggregates was then prepared and tested according to the design criteria of the Korea Ministry of Agriculture's Agricultural Production Infrastructure Maintenance Business Plan and the Korea Expressway Corporation's Highway Construction Specialized Specifications.

1. As a result of evaluating the physical properties of the air-cooled slag aggregate produced as a concrete aggregate, the quality standards (KS F 2527) of the blastfurnace slag aggregate for concrete were satisfied.

2. As a result of conducting a dissolution test in accordance with the Waste Management Act of the Ministry of Environment of the Republic of Korea and the Japanese standard JIS K 0058 to evaluate the environmental properties of the air-cooled slag aggregate, it was found that there was no effect on the dissolution of hazardous substances, as all the standards were satisfied.

3. The slump and air-content values of the experimental mixtures met the targeted performance criteria. However, the slump decreased, and the air content increased, with increasing amount of air-cooled slag aggregate. This result was because the air-cooled slag aggregate had pores on the surface compared to the natural aggregate, which increased the absorption of mixed water and the contents of air.

4. The compressive, flexural, and splitting tensile strengths of the experimental mixtures met the targeted performance criteria based on the design criteria of the Korea Ministry of Agriculture's Agricultural Production Infrastructure Maintenance Business Plan and the Korea Expressway Corporation's Highway Construction Specialized Specifications. However, as the content of the air-cooled slag aggregate increased, the strength decreased, and the coarse air-cooled slag aggregate had a greater effect on the strength reduction than the fine air-cooled slag aggregate.

5. The chloride ion penetration of the experimental mixtures met the targeted performance criterion of the design criteria of the Korea Ministry of Agriculture's Agricultural Production Infrastructure Maintenance Business Plan and the Korea Expressway Corporation's Highway Construction Specialized Specifications. In addition, the amount of chlorine ion penetration increased as the content of the air-cooled slag aggregate increased.

This study did not take into account the effects of different subsurfaces and subgrade conditions in rural areas. We assumed that the different subsurface and subgrade conditions do not affect the concrete pavement, and the performance was evaluated when air-cooled slag aggregate was used as the concrete pavement material.

Author Contributions: S.-J.L. conceived and designed the experiments; B.-H.A. performed the experiments and analyzed data; C.-G.P. analyzed data and wrote the manuscript. All authors have read and agreed to the published version of the manuscript.

Funding: This study was carried out with the support of 'R\&D Program for Forest Science Technology (Project No. 2021332B10-2123A01)' provided by Korea Forest Service(Korea Forestry Promotion Institute) and This work was supported by Korea Institute of Planning and Evaluation for Technology in Food, Agriculture, Forestry (IPET) through Agricultural Foundation and Disaster Response Technology Development Program, funded by Ministry of Agriculture, Food and Rural Affairs (MAFRA)(320047-05-2-HD020). 
Institutional Review Board Statement: Not applicable.

Informed Consent Statement: Not applicable.

Data Availability Statement: Not applicable.

Conflicts of Interest: The authors declare no conflict of interest.

\section{References}

1. Lee, J.M.; Choi, H.K.; Yoo, T.J.; Kim, Y.M. Establishing a Resource Circulation Network through the Use of Blast Furnace Slag Ready-Mix Concrete Aggregate; EIP Report; Korea Industrial Complex Corporation: Dae-gu, Korea, 2017.

2. Jeon, J.G.; Jin, S.J.; Kim, D.H. Present Status and Recycling Technology for Slag in Korea. J. Korean Recycl. Constr. Resour. Inst. 2013, 8, 8-10.

3. Choi, S.W.; Kim, V.; Jang, W.S.; Kim, E.Y. The Present Situation of Production and Utilization of Steel Slag in Korea and Other Countries. Mag. Korea Concr. Inst. 2007, 19, 28-33.

4. Korea Waste Association. Study on the Improvement of the Steel Slag Recycling System; Korea Ministry of Environment: Sejong, Korea, 2011.

5. Ryu, D.H.; Choi, S.W. The Prospect for Utilization of Blast Furnace Slag as Concrete's Aggregate. J. Korean Recycl. Constr. Resour. Inst. 2010, 5, 24-32.

6. Mun, H.Y.; Jeong, S.J.; Lim, N.K. Aggregate for concrete using industrial by-products and waste-blast furnace slag aggregate. Mag. Korea Concr. Inst. 1997, 9, 18-22.

7. Ryu, C.S. Actual State of Recycled Aggregate Utilization \& Improving Way of Construction Waste Recycle. J. Korean Recycl. Constr. Resour. Inst. 2007, 3, 23-26.

8. Park, M.S.; Kim, Y.S. A Study on the Sulfate Attack Resistance of Concrete Using EAF Slag as Fine Aggregate. J. Korean Inst. Archit. Constr. 2009, 9, 81-87.

9. Song, T.Y.; Lee, K.C.; Lee, W.P. Plan for Expanded Recycling of Recycled Aggregates as Construction Materials. J. Korean Recycl. Constr. Resour. Inst. 2016, 11, 14-17.

10. Yoo, Y.S.; Choi, H.B.; Bang, J.H.; Chae, S.C.; Kim, J.W.; Kim, J.M.; Lee, S.W. $\mathrm{CO}_{2}$ Sequestration and Utilization of Calcium-extracted Slag Using Air-cooled Blast Furnace Slag and Convert Slag. Appl. Chem. Eng. 2017, 28, 101-111.

11. Lee, D.G.; Min, G.H.; Jeong, Y.W. A Study on the Reduction of Drying Shrinkage of Mortar and Concrete Using the Expandability of Rapidly Cooled Slag Fine Aggregate. J. Korea Acad. Ind. Coop. Soc. 2015, 16, 3511-3517.

12. Lee, S.T.; Park, G.P. Mechanical Properties and Durability of Concrete Incorporating Air-Cooled Slag. J. Korea Acad. Ind. Coop. Soc. 2017, 18, 356-363.

13. Lim, H.S.; Lee, H.S. Experimental Study on Evaluation on Volume Stability of the Electric Arc Furnace Oxidizing Slag Aggregate. J. Korea Inst. Struct. Maint. Insp. 2017, 21, 78-86.

14. Jeong, W.K.; Kim, Y.S.; Bae, J.O. Development and application examples of high-performance concrete pavement repair materials using fine aggregates of oxidized slag of an electric furnace, a by-product of the steel industry. Korean Soc. Road Eng. Road 2012, 14, 39-50.

15. De MatosaJade, P.R.; Taísa, C.P.O.; Diego, M.M.; Philippe, C.M.; Rudiele, J.P.G.; Pilarb, A.S.R. Use of air-cooled blast furnace slag as supplementary cementitious material for self-compacting concrete production. Constr. Build. Mater. 2020, 262, 102-120. [CrossRef]

16. Verian, K.P.; Behnood, A. Effects of deicers on the performance of concrete pavements containing air-cooled blast furnace slag and supplementary cementitious materials. Cem. Concr. Compos. 2018, 90, 27-41. [CrossRef]

17. Ozbakkaloglu, T.; Gu, L.; Pour, A.F. Normal- and high-strength concretes incorporating air-cooled blast furnace slag coarse aggregates: Effect of slag size and content on the behavior. Constr. Build. Mater. 2016, 126, 138-146. [CrossRef]

18. Abdel-Ghani, N.T.; El-Sayed, H.A.; El-Habak, A.A. Utilization of by-pass cement kiln dust and air-cooled blast-furnace steel slag in the production of some "green" cement products. HBRC J. 2018, 14, 408-414. [CrossRef]

19. Smith, K.D.; Morian, D.A.; Van Dam, T.J. Use of Air-Cooled Blast Furnace Slag as Coarse Aggregate in Concrete Pavements-A Guide to Best Practice; FHWA-HIF-009; Federal Highway Administration: Washington, DC, USA, 2012.

20. Min, K.S.; Park, Y.K.; Lee, J.H.; Kim, H.W.; Jeong, K.Y.; Yoon, K.W. A Study on Application of PHC Pile Concrete of Aggregate using Air-cooled Blast Furnace Slag Aggregate. In Proceedings of the Korea Concrete Institute 2014 Spring Conference, Korea Concrete Institute, Jeju, Korea, 29-30 May 2014; Volume 26, pp. 341-342.

21. Korea Ministry of Agriculture, Food and Rural Affairs. Agriculture's Agricultural Production Infrastructure Maintenance Business Plan's Design Criteria; Korea Ministry of Agriculture, Food and Rural Affairs: Sejong, Korea, 2007.

22. Korea Expressway Corporation. Construction Material Quality and Standard for Highway Construction; Korea Expressway Corporation: Kimcheon, Korea, 2005.

23. KSF 2527, Concrete Aggregate; Korea Standards Association: Seoul, Korea, 2020.

24. Korea Ministry of Environment. Water Pollution Process. Test Standards; Ministry of Environment: Sejong, Korea, 2021.

25. JIS K 0058-1. Test Methods for Chemicals in Slags Part. 1: Leaching Test. Method (FOREIGN STANDARD); Japanese Standards Association: Tokyo, Japan, 2005. 
26. ASTM C143/C143M, Standard Test Method for Slump of Hydraulic-Cement Concrete; American Society for Testing and Materials: Philadelphia, PA, USA, 2020.

27. ASTM C231/C231M, Standard Test Method for Air Content of Freshly Mixed Concrete by the Pressure Method; American Society for Testing and Materials: Philadelphia, PA, USA, 2017.

28. ASTM C39/C39M, Standard Test Method for Compressive Strength of Cylindrical Concrete Specimens; American Society for Testing and Materials: Philadelphia, PA, USA, 2017.

29. ASTM C78/C78M, Standard Test Method for Flexural Strength of Concrete (Using Simple Beam with Third-Point Loading); American Society for Testing and Materials: Philadelphia, PA, USA, 2021.

30. ASTM. ASTM C496/C496M. Standard Test Method for Splitting Tensile Strength of Cylindrical Concrete Specimens; American Society for Testing and Materials: Philadelphia, PA, USA, 2011.

31. ASTM. ASTM C1202. Standard Test Method for Electrical Indication of Concrete's Ability to Resist. Chloride Ion. Penetration; American Society for Testing and Materials: Philadelphia, PA, USA, 2012.

32. Park, S.B. Construction Materials; Muneundang: Seuol, Korea, 2010.

33. Shin, K.S.; Lee, B.K.; Kim, K.Y. Durability of Concrete Using Blast Furnace Slag Powder. J. Korean Recycl. Constr. Resour. Inst. 2012, 7,13-17.

34. Lee, H.J.; Se, J.I.; Ryu, S.W. Bond Behavior of Concrete According to Replacement Ratio of Fly Ash and Compressive Strength of Concrete. J. Korean Recycl. Constr. Resour. Inst. 2016, 4, 19-24. 